\title{
Foraging ecology and choice of feeding habitat in the New Zealand Fairy Tern Sternula nereis davisae
}

\author{
STEFANIE M. H. ISMAR, TOM TRNSKI, TONY BEAUCHAMP, SARAH J. BURY, \\ DAVID WILSON, ROBYN KANNEMEYER, MARK BELLINGHAM and \\ KAREN BAIRD
}

\section{Summary}

No published information is available on the foraging ecology and choice of feeding habitat of New Zealand's rarest breeding bird: the New Zealand Fairy Tern (NZFT) Sternula nereis davisae. To address this gap, we conducted an assessment of the largest remaining breeding population at Mangawhai Harbour, Northland, New Zealand, during the chick-rearing period of the 2010/2011 breeding season. We combined visual tracking of birds with prey surveys and stable isotope analyses, and we present the first quantitative assessment of NZFT foraging. We recorded 405 foraging dives that show NZFT foraging habitat includes the water edges, shallow channels, and pools on the tidal flats of mangrove-lined (Avicennia marina var. resinifera) parts of the estuary; tidal pools on mud- and sandflats in the mid-estuary and lower harbour; the shallow margins of the dredged main channel in the lower harbour; the oxbow lagoons on the sand spit; and coastal shallows. Our study identifies the mangrove-lined highly tidal and shallow mid-estuary and the lagoon on the sand spit as foraging hotspots for the Mangawhai breeding population of the NZFT. The prey survey employed a seine-net sampling method at identified NZFT foraging sites and yielded 4,367 prey-sized fish of II species, two of which had not previously been reported in Mangawhai Harbour, as well as numerous shrimps. The most abundant fish were gobies of the genus Favonigobius. Our stable isotope results highlight gobies as the most important prey for NZFT chick rearing, also indicating that flounder Rhombosolea sp. contribute to NZFT diet. We raise the possibility that shrimps may also constitute a substantial diet component for NZFT, potentially providing up to $21 \%$ of diet mass for adult birds. While our results provide a first basis to understanding the feeding ecology of NZFT during their breeding season in order to facilitate conservation planning, further research is required to address inter-annual variation and to identify key foraging grounds for this Critically Endangered bird at other breeding sites.

\section{Introduction}

The foraging ecology and choice of feeding habitat of New Zealand's rarest breeding bird (Hansen 2005), the New Zealand Fairy Tern (hereafter: NZFT) Sternula nereis davisae (Gould 1843), have not been described to date. With a current breeding population of only nine pairs (fouryear average 2008/2009-2011/2012; DoC internal reports) at only four known breeding sites (summary of Ferreira et al. 2005, Lagnaz 2010, Meagher 2010, Smith 2010, Zimmerman 2010), the New Zealand taxon is currently ranked as nationally Critically Threatened (Miskelly et al. 2008); with the species classified globally as "Vulnerable" (IUCN 2011). In spite of intensive protection, breeding monitoring and egg and chick management by the New Zealand Department 
of Conservation (Parrish and Honnor 1997, Hansen 2005) and community volunteer efforts, the NZFT still faces an extinction risk of $39 \%$ over the next 50 years (Ferreira et al. 2005).

While the factors identifying suitable breeding habitat have recently been assessed (Brooks et al. 2011), and feeding observations at nest sites indicate the potentially crucial prey spectrum during chick rearing (Parrish and Pulham 1995a), no data on foraging habitat choice and dependency, or foraging behaviour of the NZFT have been published to date.

Reproductive success in small terns has been shown to depend heavily on proximity of productive foraging areas (Perrow et al. 2011a, for Little Tern Sternula albifrons), and availability of high quality prey for chick provisioning (Dänhardt et al. 2011, for Common Tern Sterna hirundo). The conspecific Australian Fairy Tern (AFT) S. n. nereis has been reported to rarely travel beyond $2 \mathrm{~km}$ for foraging during the breeding season (Paton and Rogers 2009). Investigation of the feeding ecology of the NZFT is warranted to guide long-term conservation actions for the taxon.

We conducted a field study at Mangawhai Harbour, Northland, New Zealand during the 2010/2011 chick-rearing period (November-January) to address this gap in knowledge. We assessed the foraging ecology of the largest remaining breeding population at Mangawhai Harbour, where five out of the 10 breeding pairs nested on the neighbouring sand spit in the 2010/2011 season (DoC internal reports). Our study combined a specifically designed visual tracking regime that collated 140 hours of direct field observations to establish NZFT foraging habitat use, with sampling by seine-net and analyses of potential prey items from 1o identified NZFT feeding sites to describe the potential NZFT prey spectrum. Stable isotope analyses offer a non-invasive tool to assess dietary composition, circumventing disruption of nest sites, as would be risked by collection of pellets and dropped prey items. We therefore used stable isotope analyses of 52 samples of feathers as well as potential prey tissues, to assess the importance of the most common estuarine fish and shrimps in NZFT diet.

\section{Materials and methods}

\section{Study species and study area}

The subspecies S. n. davisae (Mathews and Iredale 1913) of Sternula nereis (Gould 1843) only breeds in New Zealand, and is genetically distinct from its Australian and New Caledonian conspecifics (Baling and Brunton 2005). In contrast with both the Australian subspecies S. n. nereis and the New Caledonian subspecies S. n. exsul, which form breeding colonies (Bransbury 1992, Carter and Mustoe 2007, Baling et al. 2009), breeding behaviour under current ecological conditions suggests the NZFT is a solitary breeder (Falla et al. 1979) that defends its breeding territory against conspecifics (Parrish and Pulham 1995a). NZFT winter in Kaipara Harbour, New Zealand (Goffin 1978, Chamberlin and Dowding 1985, Parrish and Pulham 1995b). Immature and nonbreeding birds (Pulham, Habraken, Vaughan, Riegen, unpubl. data, Ornithological Society of New Zealand and New Zealand Wader Study Group) and failed east coast breeding pairs (Baird et al. in press) have also been found to feed and roost in this harbour during the austral summer months.

The breeding season of the NZFT at its four current breeding locations at Waipu $\left(35^{\circ} 59^{\prime} \mathrm{S}\right.$, $\left.174^{\circ} 29^{\prime} \mathrm{E}\right)$, Mangawhai $\left(36^{\circ} \mathrm{O} 6^{\prime} \mathrm{S}, 174^{\circ} 36^{\prime} \mathrm{E}\right)$, Pakiri $\left(36^{\circ} 15^{\prime} \mathrm{S}, 174^{\circ} 44^{\prime} \mathrm{E}\right)$, and Papakanui $\left(36^{\circ} 26^{\prime} \mathrm{S}\right.$, $174^{\circ} 12^{\prime} \mathrm{E}$ ) on New Zealand's North Island (Figure I) spans from September, when birds have returned to their breeding locations, to an extended post-fledging tuition period in FebruaryMarch (Preddey 2008) in the vicinity of their breeding sites. The nesting period typically encompasses October to January (Shaw 1985). NZFT nest on vegetation-free areas of sand and shell above the mean high-water mark (Parrish and Pulham 1995a). Three of the above breeding locations are prominent sand spits, the fourth, Pakiri, is on a small sand spit adjacent to a river mouth. All are characterised by an estuary on one side, and coastal shallows on the other. Mangrove Avicennia marina var. resinifera vegetation occurs in parts of all four estuaries and river inlets. 


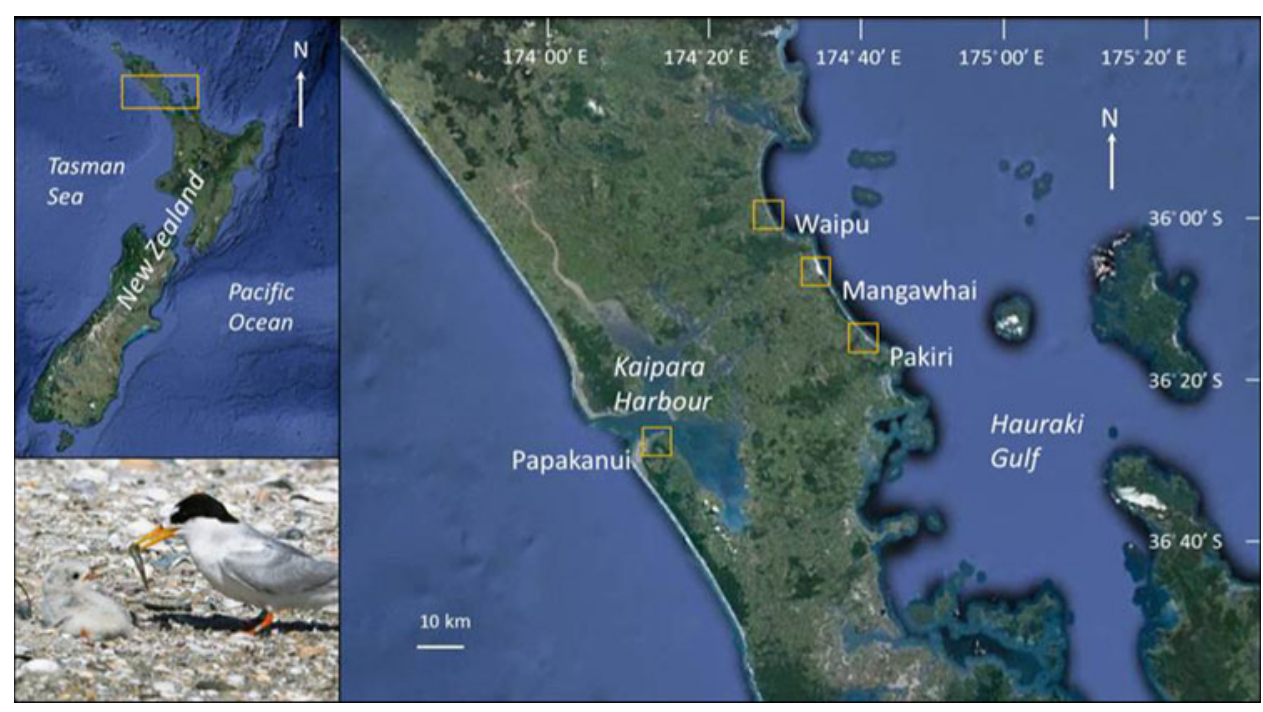

Figure 1. Breeding range of the New Zealand Fairy Tern Sternula nereis davisae; yellow symbols: the four remaining breeding locations at Waipu, Mangawhai, Pakiri and Papakanui Spit; inset: NZFT feeding a goby Favonigobius sp. to its chick, Mangawhai 2008/2009 breeding season (Photo credit: Ian Southey; satellite images: Data SIO, NOAA, U.S. Navy, NGA, GEBKO, 2010 DigitalGlobe, TerraMetrics, Google ${ }^{\mathrm{TM}}$ Earth).

At Mangawhai Harbour, a breach of the sand spit was closed by constructing a bund through the historic estuary channel in June 1996, and this created an oxbow lagoon. This lagoon was replenished by spring tides from the coastal side until 2009.

\section{Assessment of foraging habitat use}

Observations of NZFT foraging activity were collated over eight sampling events during the 2010/2011 nesting season. Sampling took place on 16, 17 and 30 Nov, on 1 and 17 Dec 2010, and on 6, 7, and 20 Jan 2011; all observation sessions lasted four hours and were timed during daylight hours spanning two hours either side of low tide. This time covered the peak NZFT foraging activity and provisioning at nests previously seen by wardens at nest sites. Given the critically endangered status of the NZFT in New Zealand, deploying biologging devices to record foraging behaviour could not be considered. Visual tracking constitutes an effective means of recording tern behaviour from the nest sites to the foraging grounds and back to the nests (Perrow et al. 2011b).

The local topography allowed us to design a cohesive observation regime (Figure 2a), monitoring the range of potential NZFT foraging habitats. Strategic observer positions were chosen that gave clear views of the mid-estuary, the lower harbour, the coastal shallows, and the lagoon, allowing simultaneous observation of any active nests. With the aid of $8 \times 40$ binoculars, and $60 \mathrm{~mm}$ zoom spotting scopes with 15-45x eye-pieces, a team of experienced observers were able to record NZFT behaviour from stationary positions at $>30 \mathrm{~m}$ from the nearest foraging habitat, which precluded any risk of displacing the focal birds or interfering with their behaviour (minimum observer distances of 20-30 m are commonly maintained for nest watches; Parrish and Pulham 1995a). Contact between observers was maintained using mobile phones, pre-notifying the next observer station as a NZFT left an observation field, aiming to follow NZFT from the time they left the nest site, to the time they returned to feed their chicks. Sighting times of NZFT and 


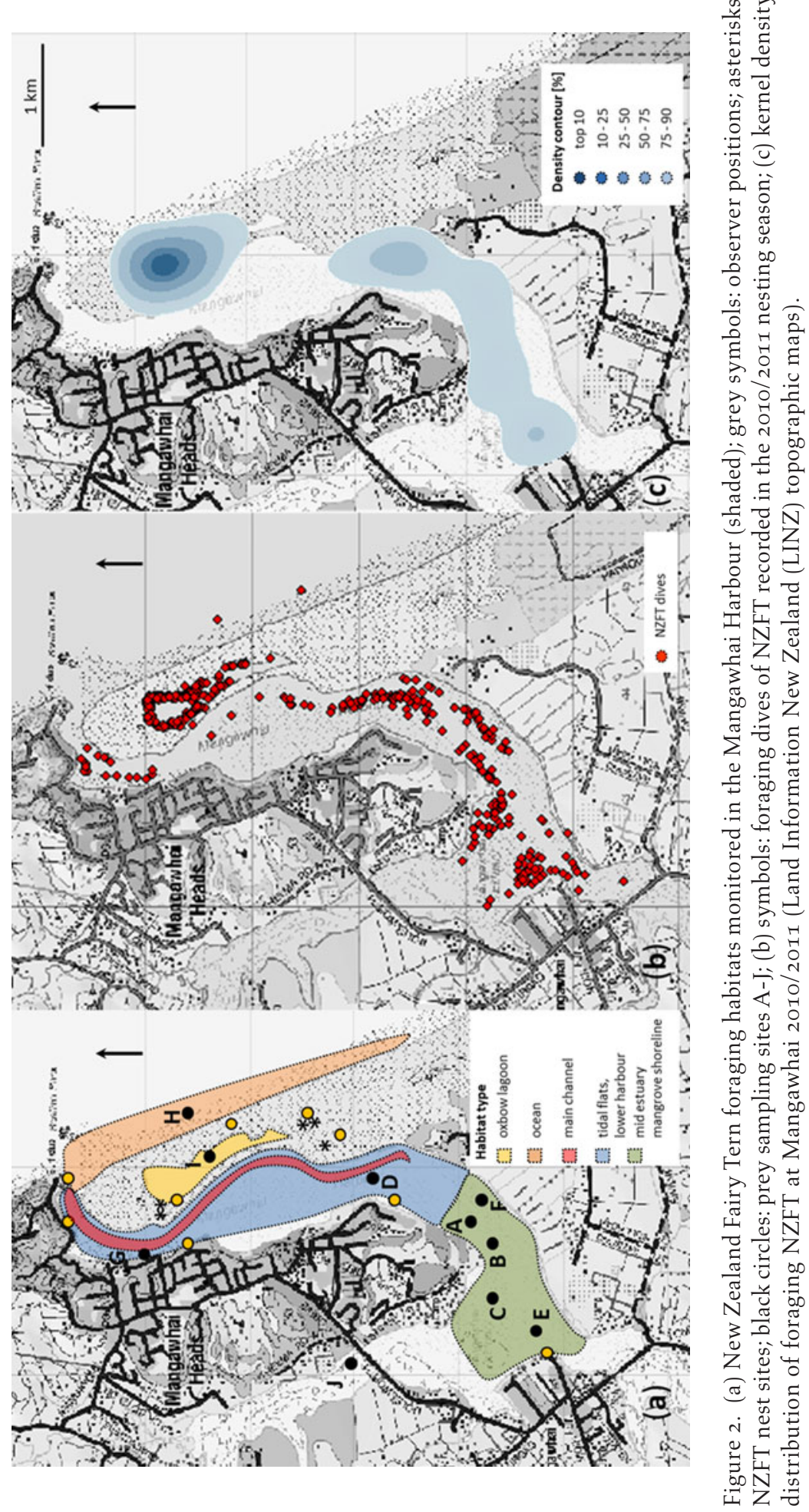


numbers of dives were quantified for each monitored habitat type, and dives were plotted using ArcMap 1o (ESRI Inc).

\section{Prey sampling}

Samples of potential prey were collected from areas where feeding activity of NZFT had been observed, using a fine-mesh beach seine net $5 \mathrm{~m}$ long and of $1.5 \mathrm{~m}$ high and mesh size of $1 \mathrm{~mm}$ with a weighted lead line that was pulled a distance of 5-30 $\mathrm{m}$; the effective sampling width averaged $4 \mathrm{~m}$. All fish samples were collected during daylight hours between o6hoo and 18 hoo and within three hours of low tide.

Three replicate tows of the seine net were taken on sampling dates between 17 Nov 2010 and 20 Jan 2011 at sampling sites A-I (Figure 2a), with sites A, B, C and I sampled twice during the austral summer and sites $E$ and $G$ sampled three times. As NZFT were observed flying upstream of the upper data collection site (observer position 5; Figure 2a) on eight occasions, an opportunistic single replicate sample was taken at site J in the upper estuary on 26 Feb 2012.

All sampled fish were identified to genus and where possible to species level, and standard length (SL) was measured to the nearest $1 \mathrm{~mm}$ for all or up to 300 specimens per taxon and haul. Fish were retained as voucher material at the Auckland Museum, New Zealand. All fish were counted and abundances standardised per $10 \mathrm{~m}$ of haul length. As fish numbers were non-normally distributed across our samples, median and interquartile ranges of the abundance of all fish taxa were calculated for each sampling site. Size-distributions of the three most abundant fish species were assessed, using pooled data from replicate hauls for each site and sampling date.

\section{Stable isotope sampling and analyses}

Potential prey sources that occurred with a median abundance of greater than zero at least at one sampling site were assessed with stable isotope analyses. These were gobies Favonigobius sp. $(n=9)$, flounder Rhombosolea sp. $(n=4)$, and shrimp $(n=6)$ caught at confirmed NZFT foraging sites; a single juvenile parore Girella tricuspidata, was included as an illustrative assessment of an oceanic prey signature. Stable isotope analyses were conducted on homogenised whole prey.

Reference prey items were snap-frozen in liquid nitrogen upon collection, and subsequently stored at $-80^{\circ} \mathrm{C}$ until freeze-drying to constant weight and homogenising. Breast feathers of 29 19-20 day-old NZFT chicks (collected at the four breeding sites during New Zealand Department of Conservation banding operations 2007-2011; one adult wing under-covert feather from a predated female tern; and feathers from two adult and two immature specimens from the Natural History Museum Vienna, Austria (NMW 48.943 ô ad., NMW 48.946 §ै immat., NMW 48.945 ㅇ ad., July 1882, Manukau, A. Reischek; NMW 48.944 unsexed immat., collected prior to July 1866, exact locality not known, probably surroundings of Christchurch, J. v. Haast), were used for stable isotope analyses. All feathers were cleansed with $70 \%$ ethanol and subsequently dried and homogenised. Approximately $0.7 \mathrm{mg}$ of sample were weighed and encapsulated in standard tin cups for stable isotope analyses.

Nitrogen (as an indicator of trophic position) and carbon (as an indicator of the primary carbon source) stable isotope ratios were determined at the National Institute for Water and Atmospheric Research (NIWA), Wellington, utilising a NA1500 (Fisons Instruments, Rodano, Italy) CHN elemental analyser linked to a Delta ${ }^{\text {Plus }}$ (Thermo-Fisher Scientific, Bremen, Germany) fully automated continuous flow isotope ratio mass spectrometer. Ratios of the rare to the common carbon $\left({ }^{13} \mathrm{C},{ }^{12} \mathrm{C}\right)$ and nitrogen $\left({ }^{15} \mathrm{~N},{ }^{14} \mathrm{~N}\right)$ isotopes were reported using delta notation, written as $\delta$, in units of parts per thousand (\%o), calculated against a limestone standard originally calibrated against the international standard Pee Dee Belemnite (for C) and against Nitrogen in air (for N). Isotope values were normalised and corrected against a suite of National Institute of Standards 
and Technology (NIST) standards. Repeat analysis of NIST and internal DL Leucine working standards produced data accurate to within $0.5 \%$ for $\delta^{15} \mathrm{~N}$ and $0.4 \%$ for $\delta^{13} \mathrm{C}$ and a precision of better than $0.25 \%$ for $\delta^{15} \mathrm{~N}$ and $0.29 \%$ for $\delta^{13} \mathrm{C}$.

\section{Data analyses}

Core NZFT foraging areas were calculated as kernel density distributions of all recorded dives using the ArcGIS 1o Spatial Analyst Tool (ESRI Inc). Density contours were set to display the top $90 \%$ of spatial use.

Mann-Whitney Rank Sum Tests were performed in SigmaPlot version I1.o (Systat Software Inc.) to compare abundance of fish per $10 \mathrm{~m}$ haul length in the mid-estuary with mangrovevegetated shorelines, to those in the lower harbour. Kruskal-Wallis Tests were subsequently run to compare abundance between all sampling sites, followed by Dunn's all pairwise multiple comparisons procedures. Kruskal-Wallis analyses were also run to test for differences in distributions of standard lengths, (a) including samples pooled from three replicate hauls at sites A-E taken on I Dec 2010, and (b) between samples from three replicate hauls taken at estuary sites A, B, C, and $\mathrm{E}$ on 07 Jan 2011. All tests were performed at a significance threshold of $\alpha=0.05$.

Likely dietary composition of adult and chick NZFT was first assessed using standard mass balance equations to determine prey proportions, assuming that only the two predominant fish taxa, goby and flounder, were consumed. Calculations followed Phillips (2001):

$$
\delta_{\mathrm{M}}=\mathrm{f}_{\mathrm{A}} \delta_{\mathrm{A}}+\mathrm{f}_{\mathrm{B}} \delta_{\mathrm{B}}
$$

and

$$
\mathrm{f}_{\mathrm{A}}+\mathrm{f}_{\mathrm{B}}=\mathrm{I}
$$

where $\delta$ represents the isotopic signatures for the mixture $M$ and for sources $A$ and $B ; f_{A}$ and $f_{B}$ are the proportions of A and B in M (Phillips and Gregg 2001).

In our case:

$$
\mathrm{f}_{\text {goby }}=\left(\delta_{\text {feather }}-\delta_{\text {flounder }}\right) /\left(\delta_{\text {goby }}-\delta_{\text {flounder }}\right)
$$

and

$$
\mathrm{f}_{\text {flounder }}=1-\mathrm{f}_{\text {goby }}
$$

for feather signatures from NZFT adults and chicks, respectively.

Means and standard errors of stable isotope signatures of NZFT feathers from chicks and adults, and prey items were calculated. A juvenile parore Girella tricuspidata caught in the oceanic shallows was included to provide the signatures of an oceanic prey item. Prey $\delta^{13} \mathrm{C}$ and $\delta^{15} \mathrm{~N}$ signatures were tested for normality and equal variance applying Shapiro-Wilk Tests, and differences between goby and flounder were assessed in unpaired two-sample t-tests. Subsequently, as shrimp also occurred in high numbers at several of our sampling sites, these were included as a third potential prey source, and compared with flounder and goby signatures in one-way ANOVAs. A prey polygon was constructed (Figure 4), assuming average assimilation rates of $3.4 \% 0 \delta^{15} \mathrm{~N}$ per trophic level, and $0.8 \%$ o $\delta^{13} \mathrm{C}$ from prey to predator, to account for fractionation during digestion and assimilation (Phillips and Gregg 2003). All possible dietary compositions were calculated using IsoSource 1.3 .1 software with $1 \%$ increments of possible source contributions and a tolerance level of o.I (Phillips and Gregg 2001, 2003) for NZFT chicks and adults respectively. 


\section{Results}

\section{Foraging habitat choice}

From 140 hours of observation effort we collated data from $30.4 \mathrm{~h}$ of NZFT attendance to nesting, foraging and roosting areas (surveying up to five active nest sites). Monitored behaviour included foraging, roosting and transit between habitats, collating 139 sightings of NZFT (Table 1). In total, 21 complete tracks from nest site to the foraging areas and back to the nest were recorded. We recorded 405 foraging dives, and observed NZFT foraging in the oxbow lagoon on the Mangawhai sand spit, the shallows of the mid-estuary with mangrove shorelines, the shallow tidal pools on flats in the lower harbour, the shallows of the channels, and the shallows of the ocean (Table 1 , Figure $2 \mathrm{~b}$ ). Their dives comprised a downward plunge with an opening of the wings so that generally the bill and head were submerged. The mid-estuary, which is characterised by at least one mangrove-vegetated shoreline and by extensive shallow channels at low tide, and the oxbow lagoons on the sand spit, in particular, were found to be core areas of NZFT foraging (Figure 2c), as well as hosting most roosting behaviour (Table 1 ).

\section{Prey abundance}

Seine net sampling yielded 4,368 fish of at least 11 species, encompassing eight families, and shrimps including thousands of carids and mysids (Table 2). For two fish species, the bridled goby Arenigobius bifrenatus and the glass goby Gobiopterus semivestitus, these are the first records from Mangawhai Harbour. Estuarine gobies Favonigobius sp. contributed 92.8\% of fish samples; and shrimps constituted the second most abundant taxon with roughly 2,000-3,000 individuals. The glass goby and bridled goby were the second and the third most abundant fishes, but each occurred at only a single sampling site. The bridled goby was only found in the lagoon and the glass goby at site J in the upper estuary. Small sand flounders (which were predominantly yellowbelly flounder $R$. leporina) regularly occurred in small numbers at sampling sites throughout the estuary.

Favonigobius sp. were highly significantly more abundant at sampling sites within the midMangawhai Harbour (pooled A-C, E, F), than at sampling sites in the lower harbour (pooled D, G) (Mann-Whitney $U$ statistic $1.00, T_{12,30}=79.00, P<0.001$ ). Kruskal-Wallis analyses revealed significant differences in numbers of Favonigobius sp. between sampling sites $\left(H_{8}=34.13, P<0.001\right)$, particularly when only sites within Mangawhai Harbour were included $\left(H_{6}=28.93, P<0.001\right)$. Subsequent Dunn's pairwise multiple comparisons showed that B (diff of ranks $=19.89, Q=3.08$, $P<0.05$ ), $C$ (diff of ranks $=27.56, Q=4.26, P<0.05$ ), and $E$ (diff of ranks $=24.28, Q=4.20$, $P<0.05$ ) had significantly higher Favonigobius sp. abundance than site G. There were no

Table 1 . Summary of attendance, including foraging, roosting and transit behaviour of the New Zealand Fairy Tern (NZFT) population at NZFT habitats at Mangawhai in the 2010/2011 nesting season.

\begin{tabular}{|c|c|c|c|c|c|}
\hline Habitat type & Description & $\begin{array}{l}\text { Number } \\
\text { of dives } \\
\text { recorded }\end{array}$ & $\begin{array}{l}\text { Proportion } \\
\text { of dives } \\
\text { recorded }\end{array}$ & $\begin{array}{l}\text { Observer } \\
\text { effort [h] }\end{array}$ & $\begin{array}{l}\text { NZFT } \\
\text { attendance } \\
{[\mathrm{min}]}\end{array}$ \\
\hline Mid estuary & $\begin{array}{l}\text { Shallow tidal channels and pools, } \\
\text { mud- and sand flats, at least one } \\
\text { shoreline vegetated by mangroves }\end{array}$ & 138 & 0.341 & 28 & 981 \\
\hline Lower harbour & Tidal pools on mud- and sand flats & 58 & 0.143 & 28 & 271 \\
\hline Main channel & Shallows along the water edges & 24 & 0.059 & 32 & 79 \\
\hline Lagoon & Shallows along the water edges & 183 & 0.452 & 32 & 313 \\
\hline \multirow[t]{2}{*}{ Ocean shallows } & $\begin{array}{l}\text { Roosting on beach, foraging just } \\
\text { beyond breaking waves }\end{array}$ & 2 & 0.005 & 20 & 180 \\
\hline & & 405 & & 140 & \\
\hline
\end{tabular}




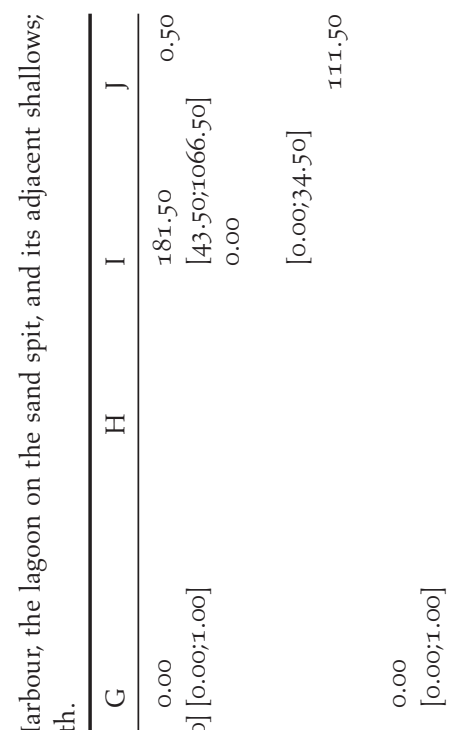

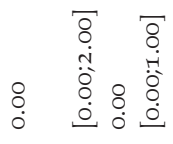

$\overbrace{\substack{n \\ \hdashline}}^{\infty}$

$\begin{array}{ll}8 \\ \infty \\ i & \stackrel{\pi}{0} \\ i & 0\end{array}$

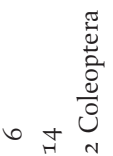

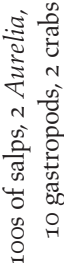

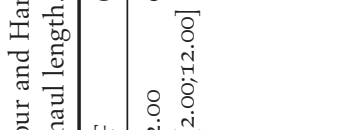

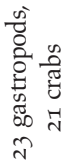

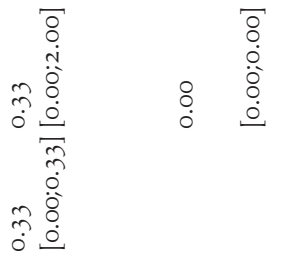

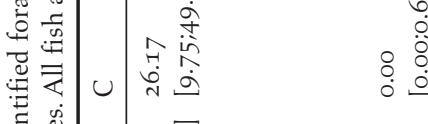

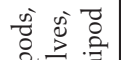

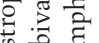

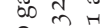

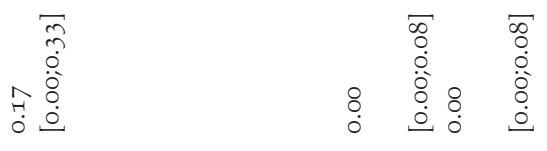

प्रें

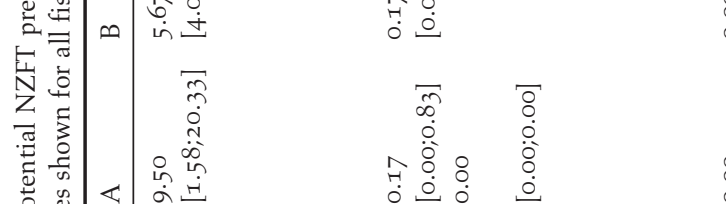

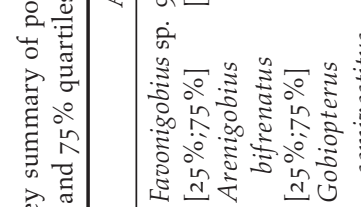

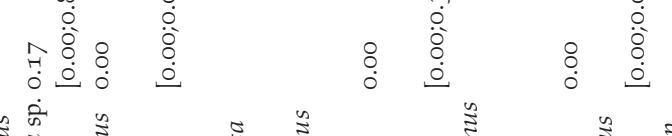

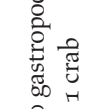

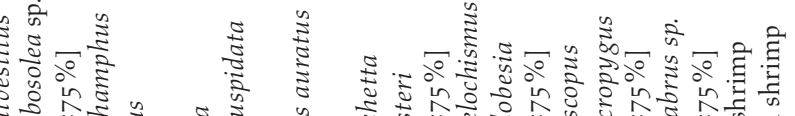

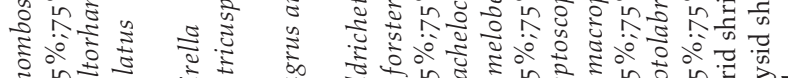

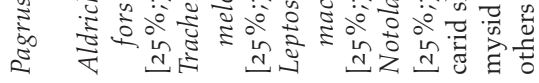

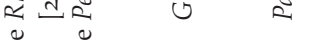

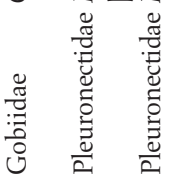

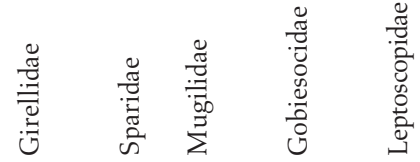

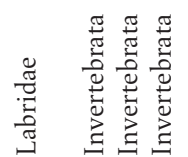


significant differences in Rhombosolea sp. abundance between sampling sites included in our study overall $\left(H_{8}=9.70, P=0.29\right)$, nor within the Mangawhai Harbour $\left(H_{6}=3.89, P=0.69\right)$.

Size distributions of Favonigobius sp. ranged from $18-38 \mathrm{~mm} \mathrm{SL} \mathrm{(A),} \mathrm{24-40} \mathrm{mm} \mathrm{(B),} \mathrm{20-40} \mathrm{mm}$ (C), 23-41 $\mathrm{mm}(\mathrm{E})$, and $24-35 \mathrm{~mm}(\mathrm{~F})$ in the mid-estuary, from $35-41 \mathrm{~mm}(\mathrm{D})$ in the lower harbour, and from $18-44 \mathrm{~mm}$ (I) in the oxbow lagoon during Nov-Dec 2010. In 7 Jan samples, smaller size classes were collected: $8-20 \mathrm{~mm} \mathrm{SL}$ at C $(n=227$, SL $7-19 \mathrm{~mm})$, and low numbers of small specimens occurred at sites A $(n=1,12 \mathrm{~mm} \mathrm{SL}), \mathrm{B}(n=4,12-18 \mathrm{~mm})$, and $\mathrm{E}(n=3$, 12-15 mm SL) (Figure 3).

Differences in SL distributions of Favonigobius were highly significant amongst sampled sites (A-E) in Mangawhai Harbour on 1 Dec $2010\left(H_{4}=112.80, P<0.001\right)$ and on 7 Jan 2011 (A-C, E; $H_{3}=374.07, P<0.001$; Table $\mathrm{S}_{1}$ in the online supplementary material).

\section{Dietary composition}

Feather stable isotope signatures of NZFT chicks were $14.37 \pm 0.90 \%$ o $\delta^{15} \mathrm{~N}$ and $-15.61 \pm 1.65 \%$ o $\delta^{13} \mathrm{C}$, those of adult birds $14.82 \pm 1.85 \% 0 \delta^{15} \mathrm{~N}$ and $-15.53 \pm 1.52 \% 0 \delta^{13} \mathrm{C}$ (Figure 4). Stable isotope signatures of museum specimens are additionally depicted separately in Figure 4; of these the lowest signature (12.61\%o $\delta^{15} \mathrm{~N},-18.25 \% 0 \delta^{13} \mathrm{C}$ ) originated from an unsexed immature specimen which was probably collected in the surroundings of Christchurch, South Island.

Mass balance equations determined NZFT chick feather signatures were most likely the result of feeding on $80 \%$ by mass of gobies and $20 \%$ by mass of flounder, with proportions of $78 \%$ by mass of gobies and $22 \%$ by mass of flounders for the diet of adult birds. Flounder Rhombosolea sp. were significantly enriched in ${ }^{13} \mathrm{C}$ compared to gobies Favonigobius sp. $\left(T_{11}=-7.87, P<0.001\right.$; Figure 4). Nitrogen isotope signatures, in contrast, did not differ significantly between gobies and flounders $\left(T_{11}=-1.45, P=0.17\right)$. Shrimp $\delta^{13} \mathrm{C}$ signatures were not significantly different from other potential prey (ANOVA $F_{2}=3.41, P=0.06$ ); the differences in mean $\delta^{15} \mathrm{~N}$ values were significant between all prey groups when shrimp were included in the analyses (ANOVA $\left.F_{2}=12.94, P<0.001\right)$.

IsoSource modelling showed that gobies constituted the most substantial part of chick diet (with a likely range of $59-82 \%$ by mass), followed by flounders (18-22\%) and may have included shrimps as potential prey (o-19\% mass). The diet of adult NZFT was modeled to comprise $47-74 \%$ goby, 19-32\% flounder, and o-21\% shrimp.

\section{Discussion}

Weighing only c.70 g, the NZFT is the smallest tern found in New Zealand (Falla et al. 1979). In contrast to sympatric larger tern species, such as White-fronted Tern Sterna striata (Bräger 1998), the NZFT is not a plunge diver, but commonly feeds within the upper few centimeters of water. The NZFT typically breaks the momentum of its descending aerial dive just above the water surface by spreading its tail and wings, submerging usually just the bill, and part of its head, to seize prey (Fig. $S_{1}$ in the online supplementary material). We estimate, based on culmen and head morphometrics, that if only the bill and head are immersed, as commonly observed in this study, these terns can feed on approximately the upper $5-8 \mathrm{~cm}$ of the water. This foraging method also enables the bird to utilise extremely shallow waters, such as tidal pools. Indeed, the breeding distribution of NZFT indicates that this subspecies only persists in shallow estuarine environments, which is consistent with the generally reported breeding habitat of the species (Higgins and Davies 1996).

NZFT had previously been observed to feed gobies Favonigobius lentiginosus, elvers Anguilla sp., and flounder Rhombosolea sp. to their chicks, with provisioning rates of $\sim 0.5^{-2} \mathrm{fish} / \mathrm{h}$ (Parrish and Pulham 1995a) to peak provisioning bouts of four fish per 8-minute period during post-fledging parental care (Preddey 2008). The core $90 \%$ of NZFT foraging habitat fell almost exclusively on the oxbow lagoon on the sand spit, and in the mid-estuary that had at least one 

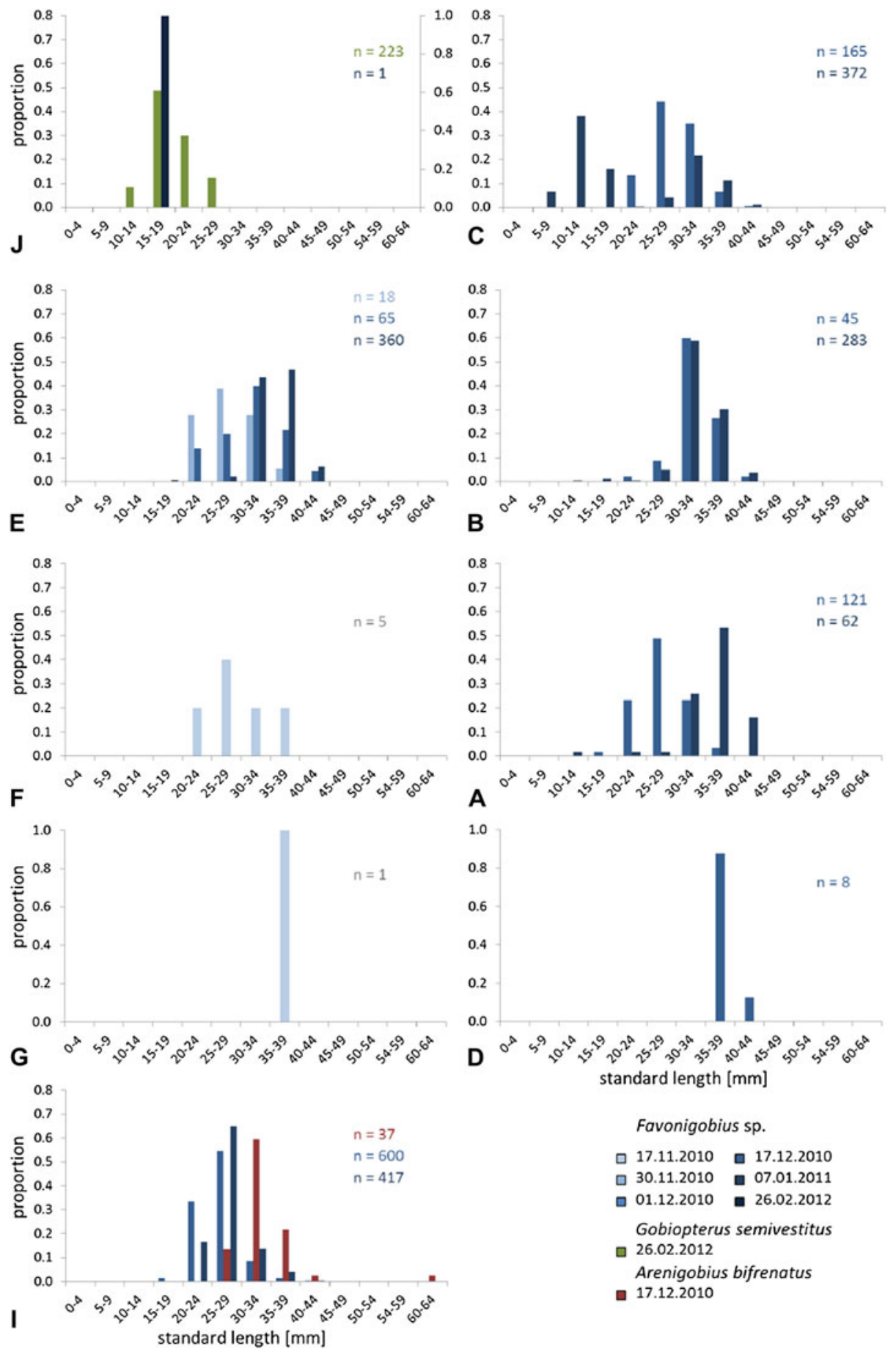

Favonigobius sp.

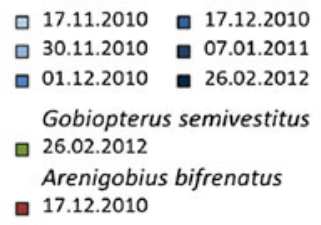

Figure 3. Size-distributions of Favonigobius sp., Arenigobius bifrenatus, and Gobiopterus semivestitus at sampling sites A-J, Mangawhai, plotted in order from upstream to downstream. No gobies were caught in the ocean (Site $\mathrm{H}$ ). 


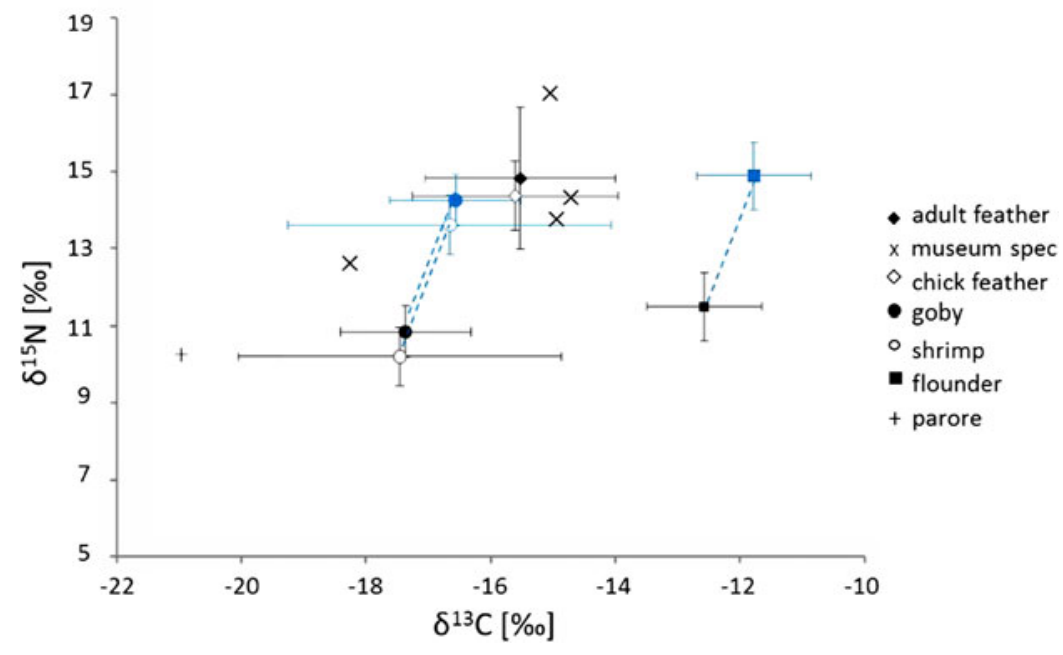

Figure 4. Carbon and nitrogen stable isotope signatures (means and standard deviations) of New Zealand Fairy Tern feathers of adults and chicks, and potential prey taxa identified from seine net sampling (black symbols). Prey signatures, plus the fractionation factor of $3.4 \%$ for $\mathrm{N}$ and $0.8 \%$ for $\mathrm{C}$, are indicated by blue symbols, where the dotted lines show the fractionation increment from the measured prey tissue isotope values.

mangrove-vegetated shoreline. The shallows of the main channel in the lower harbour, and the shallows of the ocean were within the least densely used 10\% of NZFT foraging habitats during our time of study. Our results indicate that those areas where suitable prey was most abundant were frequented most by NZFT for foraging, and we note that within those, the shallows were used most of all. Favonigobius sp., which according to our stable isotope source apportioning results constitute the main prey of NZFT, shelter in the pneumatophore zones provided by prop roots along the edges of mangroves at high tide. Consequently, highest goby abundance is associated with mangrove edges, with their distributions extending into mangrove stands and onto adjacent mudflats (Hindell and Jenkins 2005). As the tide lowers and the mangrove-vegetated areas and adjacent tidal flats fall dry, gobies move with the water into the channels and tidal pools of the upper and mid-estuary. Small-sized estuarine gobies can be flushed into the ocean where tidal currents are strong (Young and Potter 2003), but adult fish are able to largely stay within their preferred estuarine habitats when subject to tidal ranges as found at our study site (Gill and Potter 1993, Potter and Hyndes 1999). This is consistent with the low numbers of gobies overall, and the absence of specimens $<35 \mathrm{~mm}$ in the lower Mangawhai Harbour in our study. The recorded fish were suitably sized for NZFT prey (Figure 3), with only one specimen exceeding $9 \mathrm{~cm}$, the maximum prey size to date observed to be taken by a NZFT (G. Pulham unpubl. data).

The bimodal size distribution of Favonigobius sp. (Figure 3) at site $\mathrm{C}$ in January showed settlement of a new size class. Minimum sizes of 1 I $\mathrm{mm}$ and $9 \mathrm{~mm}$ are reported respectively for the two species of Favonigobius reported in New Zealand, F. lentiginosus and F. exquisitus (Chargulaf et al. 2011), indicating recent settlement of Favonigobius larvae at mid-estuary site $\mathrm{C}$ during our January sampling at Mangawhai. These parts of the Mangawhai Harbour currently provide the suitable flow regimes (sensu Strydom et al. 2002) to enable settlement and retention of Favonigobius larvae. No recruitment was evident in the lagoon by January 2010.

Our results highlight gobies as the most important prey for NZFT chick rearing, and indicate that most NZFT prey is likely to be of estuarine, rather than oceanic, origin. Yet, large variation 
in chick $\delta^{13} \mathrm{C}$ values may indicate a variation in the contribution of oceanic prey to offspring provisioning in NZFT between different breeding sites and years.

Nitrogen stable isotope data showed flounders and gobies to be at a similar trophic level. The ${ }^{13} \mathrm{C}$-enriched signatures of flounders compared to other fish taxa that were sampled, indicates a strictly benthic feeding habit of Rhombosolea spp. Favonigobius sp., in contrast, had significantly lower $\delta^{13} \mathrm{C}$ values than flounders, indicating a more planktonic diet. This is consistent with recent findings that Favonigobius spp. selectively feed on copepods and decapod shrimps (Chargulaf et al. 2011), which occurred in our samples from the mid-estuary and lagoon, and which may also aggregate in mangrove pneumatophore systems at high tide (Modlin 1990, Buskey 1998, 2000). The stable isotope signatures we measured for shrimp suggested that these are indeed likely prey for gobies in the Mangawhai Harbour and oxbow lagoon, although smaller size-classes of shrimp would not have been captured quantitatively by our seine net sampling (the mesh size of $1 \mathrm{~mm}$ would have under-sampled mysids that have a body width and height $<1 \mathrm{~mm}$ ).

These integrative findings highlight the nursery role of the mid-estuary (Chang et al. 2006, Strydom et al. 2003) for the most quantitatively important NZFT prey. The shallow topography, together with the structure provided by mangrove roots during the flood phase of the tidal cycle, would reduce current flow, enabling the successful transition in gobies from pelagic larvae to benthic juveniles. Mangrove roots also provide a refuge for adult gobies at high tide (Hindell and Jenkins 2005), and additionally increase goby abundance by providing sites for aggregations of their prey (Buskey 1998, 2000).

Our stable isotope results indicate that shrimps could be a substantial diet component for NZFT, potentially contributing up to $21 \%$ of the mass. In the 2011/2012 breeding season, adult NZFT were observed taking shrimp from the oxbow lagoon at Mangawhai (R. Zimmerman pers. obs.), but shrimp have never been recorded as food items delivered to chicks. Shrimps are likely to be of lower nutritional value than fish for chick rearing, and some foraging adult terns have been shown to distinguish between food items to be ingested by themselves, and those suitable for feeding to their offspring (Dänhardt et al. 2011). In many cases it was impossible to ascertain whether prey was captured by foraging NZFT during our study. Shrimps are less conspicuous than fish to human observers using binoculars or a spotting scope to monitor bird behaviour, and may, if ingested immediately upon capture, go undetected by the observer.

Productive foraging grounds in the vicinity of the breeding sites are vital in enabling the high chick provisioning rates observed in NZFT (Parrish and Pulham 1995a, Preddey 2008). Without productive feeding grounds close to the nesting locations of NZFT, sufficiently frequent nuptial feeding of the incubating female and of the chicks at the nest, or local post-fledging tuition of offspring will not be possible. Reproductive failure in the conspecific AFT has been found to be associated with lack of suitable prey in the proximity of the breeding area in the Coorong (Paton and Rogers 2009), and recent declines in the Coorong AFT population coincided with a dramatic distribution contraction of small-mouthed hardyhead Atherinosoma microstoma as suitable prey for AFT (Paton et al. 2009).

Striking evidence of the direct linkage between impeded local foraging success near the breeding site and reduced reproductive output also comes from the congeneric Little Tern Sternula albifrons at its most important UK colony (Perrow et al. 2006, 2011a). In this close relative of the Fairy Tern (Bridge et al. 2005), construction of an offshore wind farm has led to a significant decline in the abundance of young-of-the-year clupeids, a major part of the diet for these Little Terns. This decline was associated with reduced foraging success in the birds, and unprecedented rates of egg abandonment and hatching failure (Perrow et al. 2011a).

Reduced foraging success as a result of major feeding habitat modification could similarly result in a decline in reproductive success of the NZFT at its most important breeding site at Mangawhai, New Zealand. This could cause a significant increase in the (already high) extinction risk of this Critically Endangered bird.

Apart from high prey abundances, a range of other factors are likely to additionally benefit the foraging activity of NZFT in the mid-Mangawhai Harbour. These include low disturbance rates 
(Jeffries 2000) by walkers and dogs along currently mangrove-vegetated shores of this part of the estuary, no disturbance by motor-driven vessels at low tide, when the main channels are currently not navigable in this part of the harbour, and improved water clarity that may facilitate detection of prey.

Further research is needed to assess pivotal NZFT foraging habitats at other breeding sites, and across years. A crucial future research direction will also be assessment of prey selectivity per se: NZFT very likely select prey taxon-specifically by size, for example only relatively small flatfish can be ingested due to their body shape, while relatively large gobies would be preferable, offering a more substantial meal size and better detectability. As we had to avoid possible disruption and displacement of foraging birds, we could not select observer distances that would have allowed us to gather sufficient data on what size of prey was taken at the foraging grounds. Our results present a first basis for understanding, protecting and managing the food sources and the feeding and breeding habitats of the NZFT, which will be crucial to ensure this bird's survival.

\section{Supplementary Material}

The supplementary materials for this article can be found at journals.cambridge.org/bci

\section{Acknowledgements}

This project was carried out under New Zealand Department of Conservation Research Permit AK-29785-RES and Ministry of Fisheries Special Permit 422. Funding was provided by the Faculty of Science of the University of Auckland to SMHI, and by the Royal Forest \& Bird Protection Society of New Zealand Inc. and a BirdLife International Research Grant to SMHI and KB. We thank Alison Davis, Bev Woods, Darryl Jeffries, Jane Vaughan, Mandy Herrick, Jessa Cochrane and Bailey Lovett for help in the field, Gwenda Pulham, Rangi Zimmerman, Linda Wilson and Ernst Bauernfeind for helpful advice, Das Naturhistorische Museum Wien for generous provision of samples, and Leandro Bugoni and one anonymous referee for helpful comments. We gratefully acknowledge the Department of Conservation, Warkworth and Whangarei Offices, and About Tern Volunteers for their advice throughout our project.

\section{References}

Baling, M. and Brunton, D. (2005) Conservation genetics of the New Zealand Fairy Tern (Sterna nereis davisae). Unpublished report to the New Zealand Department of Conservation.

Baling, M., Jeffries, D., Barre, N. and Brunton, D. H. (2009) A survey of Fairy Tern (Sterna nereis) breeding colonies in the Southern Lagoon, New Caledonia. Emu - Austral Ornithol. 109: 57-61.

Baird, K., Ismar, S. M. H., Wilson, D., Plowman, S., Zimmerman, R. and Bellingham, M. (2013) Sightings of New Zealand Fairy Tern (Sternula nereis davisae) in the Kaipara Harbour following nest failure. Notornis. 6o: $183-185$.

Bransbury, J. (1992) Fairy Tern breeding records from south-eastern South Australia. South Aust. Ornithologists 31: 91.

Bräger, S. (1998) Feeding associations between White-Fronted Terns and Hector's Dolphins in New Zealand. Condor 100: 560-562.

Bridge, E. S., Jones, A. W. and Baker, A. J. (2005) A phylogenetic framework for the terns (Sternini) inferred from mtDNA sequences: implications for taxonomy and plumage evolution. Mol. Phylogen. Evol. 35: 459-469.

Brooks, J., Davis, A., Baird, K., Bellingham, M. and Zimmerman, R. (2011) Issues and options for the recovery of the Critically Endangered New Zealand Fairy Tern. Parts 1 \& 2. Auckland, New Zealand: Royal Forest \& Bird Protection Society.

Buskey, E. J. (1998) Energetic cost of positionholding behaviour in the planktonic mysid Mysidium columbiae. Mar. Ecol. Progr. Ser. 172: 139-147. 
Buskey, E. J. (2000) Role of vision in the aggregative behaviour of the planktonic mysid Mysidium columbiae. Mar.Biol. 137: 157-165.

Carter, M. and Mustoe, S. (2007) Another form of Fairy Tern (Sterna nereis) breeding in Australian territory. Aust. Field Ornithol. 24: 167-179.

Chamberlin, S. and Dowding, J. (1985) Fairy Terns at Tapora, Kaipara Harbour. Notornis 32: 324-325.

Chang, M., Wang, C., You, C. and Tzeng, W. (2006) Individual-based dispersal patterns of larval gobies in an estuary as indicated by otolith elemental fingerprints. Scientia Marina 70: 165-174.

Chargulaf, C. A., Krück, N. C. and Tibbetts, I. R. (2011) Does sympatry affect resource use in congeneric tidepool fishes? A tale of two gobies Favonigobius lentiginosus and Favonigobius exquisitus. J. Fish Biol. 97: 1968-1983.

Dänhardt, A., Fresemann, T. and Becker, P. H. (2011) To eat or to feed? Prey utilization of Common Terns Sterna hirundo in the Wadden Sea. J. Ornithol. 152: 347-357.

Falla, R.A, Sibson, R. B. and Turbott, E. G. (1979) The new guide to the birds of New Zealand. Auckland, New Zealand: Collins.

Ferreira, S. M., Hansen, K. M., Parrish, G. R., Pierce, R. J., Pulham, G. A. and Taylor, S. (2005) Conservation of the Endangered New Zealand Fairy Tern. Biol. Conserv. 125: 345-354.

Gill, H. S. and Potter, I. C. (1993) Spatial segregation amongst goby species within an Australian estuary, with a comparison of the diets and salinity tolerance of the 2 most abundant species. Mar. Biol. 117: $515-526$.

Goffin, R. B. (1978) Unusual flock of Fairy Terns. Notornis 25: 331 .

Gould, J. (1843) Untitled [= 'Mr. Gould exhibited and characterized the following thirty new species of Australian birds...']. Proc. Zool. Soc. London for 11 October 1842: 131-140. [Published in February 1843].

Hansen, K. (2005) New Zealand Fairy Tern (Tara-iti) Sterna nereis davisae recovery plan 2005-2015. Wellington, New Zealand: Department of Conservation. (Threatened Species Recovery Plan No. 57).
Hindell, J. S. and Jenkins, G. P. (2005) Assessing patterns of fish zonation in temperate mangroves, with emphasis on evaluating sampling artefacts. Mar. Ecol. Progr. Ser. 290: 193-205.

Higgins, P. J. and Davies, S. J. J. F., eds. (1996) Handbook of Australian, New Zealand and Antarctic birds. Volume 3. Snipe to pigeons. Melbourne: Oxford University Press.

IUCN (2011) Sterna nereis. In IUCN Red List of Threatened Species. Version 2011.1. International Union for Conservation of Nature. Retrieved 15 August 2011.

Jeffries, D. S. (200o) Disturbance and breeding behaviour of Fairy Terns and White Fronted Terns at Papakanui Spit. MSc Thesis, University of Auckland, Auckland, New Zealand.

Lagnaz, E. (2010) Monitoring and management of New Zealand Fairy Terns (Sterna nereis davisae) and other shorebirds at Pakiri, 2009-2010. Warkworth, New Zealand: Department of Conservation. (Internal report).

Mathews, G. M. and Iredale, T. (1913) A reference list of the birds of New Zealand. Ibis 55: 201-262.

Meagher, A. (2010) PostOp Report for NZ Fairy Tern breeding season Waipu Wildlife Refuge and overview of Northland NZ Fairy Tern project 2009/2010. Whangarei, New Zealand: Department of Conservation. (Internal Report).

Miskelly, C. M., Dowding, J. E., Elliot, G. P., Hitchmough, R. A., Powlesland, R. G., Robertson, H. A., Sagar, P. M., Scofield, R. P. and Taylor, G. A. (2008) Conservation status of New Zealand birds. Notornis 55: 117-135.

Modlin, R. F. (1990) Observations on the aggregative behaviour of Mysidium columbiae the mangrove mysid. Mar. Ecol. I1: 263-275.

Parrish, R. and Honnor, L. (1997) New Zealand Fairy Tern (Tara-iti) Sterna nereis davisae Recovery Plan 1997-2002. Wellington, New Zealand: Department of Conservation. (Threatened Species Recovery Plan No. 23).

Parrish, G. R. and Pulham, G. A. (1995a) Observations on the breeding of the New Zealand Fairy Tern. Tane 35: 161-173. 
Parrish, G. R. and Pulham, G. A. (1995b) Population size, productivity and post breeding movements of the New Zealand Fairy Tern. Tane 35: 175-181.

Paton, D. C. and Rogers, D. J. (2009) Ecology of breeding fairy terns Sterna nereis in the Coorong. Final report for the Wildlife Conservation Fund.

Paton, D. C., Rogers, D. J., Hill, B. M., Bailey, C. P. and Ziembicki, M. (2009) Temporal changes to spatially stratified waterbird communities of the Coorong, South Australia: implications for the management of heterogenous wetlands. Anim. Conserv. 12: 408-417.

Perrow, M. R., Skeate, E. R., Lines, P., Brown, D. and Tomlinson, M. L. (2006) Radio telemetry as a tool for impact assessment of wind farms: the case of Little Terns Sterna albifrons at Scroby Sands, Norfolk, UK. Ibis 148: 57-75.

Perrow, M. R., Gilroy, J. J., Skeate, E. R. and Tomlinson, M. L. (2011a) Effects of the construction of Scroby Sands offshore wind farm on the prey base of Little Tern Sternula albifrons at its most important UK colony. Mar. Pollution Bull. 62: 1661-1670.

Perrow, M. R., Skeate, E. R. and Gilroy, J. J. (2011b) Visual tracking from a rigid-hulled inflatable boat to determine foraging movements of breeding terns. J. Field Ornithol. 82: 68-79.

Phillips, D. (2001) Mixing models in analyses of diet using multiple stable isotopes: a critique. Oecologia 127: 166-170.

Phillips, D. L. and Gregg, J. W. (2001) Uncertainty in source partitioning using stable isotopes. Oecologia 127: 171-179.

Phillips, D. L. and Gregg, J. W. (2003) Source partitioning using stable isotopes: coping with too many sources. Oecologia 136: 261-269.
Potter, I. C. and Hyndes, G. A. (1999) Characteristics of the ichthyofaunas of southwestern Australian estuaries, including comparisons with holarctic estuaries and temperate estuaries elsewhere in Australia: A review. Aust. J. Ecol. 24: 395-421.

Preddey, J. M. (2008) Post-fledging care of a juvenile New Zealand Fairy Tern (Sterna nereis davisae). Notornis 55: 159-161.

Shaw, P. W. (1985) Fairy Tern. In C. J. R. Robertson, ed. Reader's Digest complete book of New Zealand birds. Sydney, Australia: Reader's Digest.

Smith, S. (2010) Tara-iti summary report for Papakanui, 2009-2010. Warkworth, New Zealand: Department of Conservation. (Internal Report).

Strydom, N. A., Whitfield, A. K., and Wooldridge, T. H. (2002) The influence of altered freshwater flow regimes on larval and juvenile Gilchristella aestuaria (Pisces: Clupeidae) abundance in the upper reaches of two South African estuaries. Mar. Freshwater Res. 53: 431-438.

Strydom, N. A., Whitfield, A. K., and Wooldridge, T. H. (2003) The role of estuarine type in characterizing early stage fish assemblages in warm temperate estuaries, South Africa. African Zool. 38: 29-43.

Young, H. C. and Potter, I. C. (2003) Do the characteristics of the ichthyoplankton in an artificial and a natural entrance channel of a large estuary differ? Estuar. Coast. Shelf Sci. 56: 765-779.

Zimmerman, R. (2010) New Zealand Fairy Tern monitoring report, Mangawhai Wildlife Refuge 2009-2010 breeding season. Whangarei, New Zealand: Department of Conservation. (Internal Report).

\section{STEFANIE M. H. ISMAR ${ }^{1,2,3 *}$, ROBYN KANNEMEYER ${ }^{2}$, MARK BELLINGHAM³ KAREN BAIRD ${ }^{3}$ \\ ${ }^{1}$ GEOMAR Helmholtz Centre for Ocean Research, Experimental Ecology, \\ Düsternbrooker Weg 20, 24105 Kiel, Germany. \\ ${ }^{2}$ School of Biological Sciences, University of Auckland, Private Bag 92019, Auckland, New Zealand. \\ 3Royal Forest \& Bird Protection Society New Zealand, PO Box 108 055, Auckland, New Zealand.}

\section{TOM TRNSKI}

Auckland Museum, Private Bag 92018, Victoria St. West, Auckland, New Zealand. 


\section{TONY BEAUCHAMP}

Department of Conservation, TSO Ecology and Environment, Northland Conservancy, PO Box 842, Whangarei, New Zealand.

\section{SARAH J. BURY}

National Institute for Water and Atmospheric Research, 301 Evans Bay Parade, Kilbirnie, Wellington, New Zealand.

\section{DAVID WILSON}

Department of Conservation, Auckland Conservancy, Warkworth, New Zealand.

*Author for correspondence; email: sismar@geomar.de

Received 12 April 2012; revision accepted 8 November 2012; Published online 22 July 2013 